\title{
The Impact of Controlling Shareholder Equity Pledge on R\&D Investment
}

\author{
Jieming Chen \\ College of Management, Jinan University, Guangzhou, China \\ Email: chenjm228@163.com
}

How to cite this paper: Chen, J.M. (2019) The Impact of Controlling Shareholder Equity Pledge on R\&D Investment. American Journal of Industrial and Business Management, 9, 2129-2143. https://doi.org/10.4236/ajibm.2019.912141

Received: November 11, 2019

Accepted: December 14, 2019

Published: December 17, 2019

Copyright $\odot 2019$ by author(s) and Scientific Research Publishing Inc. This work is licensed under the Creative Commons Attribution International License (CC BY 4.0).

http://creativecommons.org/licenses/by/4.0/

\begin{abstract}
Based on the perspective of control rights shifting, this paper investigates whether the equity pledge of controlling shareholders will decrease the $R \& D$ investment of companies in a sample of 2010-2017 years' non-financial listed companies with A-share in Shanghai and Shenzhen. The study found that the controlling shareholder equity pledge has negative impact on company R\&D investment.
\end{abstract}

\section{Keywords}

Controlling Shareholder Equity Pledge, R\&D Investment, Control Right Shifting

\section{Introduction}

As an emerging financing method, equity pledge has the advantages of non-distributed equity, low cost and convenient process compared with other financing methods. Therefore, it is favored by shareholders and listed companies and gets exploding growth in capital market of China in the last ten years. According to statistics of the Wind Economic Database, as of March 2019, the market value of pledge was 48,220 billion yuan, and the number of market pledged shares was 629 billion shares, accounting for $9.69 \%$ of the total share capital. However, affected by multiple factors such as the sharp adjustment of the capital market and the promulgation of the new rules for equity pledge, the equity pledge business is highly sought but it also has great risks. Firstly, if the stock price falls to the warning line and the controlling shareholder fails to cover positions or increase other collateral in time, the controlling shareholder may lose control and even cause the stampede effect of the secondary market, which will further trigger the stock price collapse. In order to avoid the risk of loss of company control right, companies actively or passively leave part of the funds inside the company and 
reduce dividends and R\&D expenditures. Secondly, the high pledge ratio of controlling shareholders has aggravated the second type of agency problems of listed companies, and weakening the incentive effect and enhancing the encroachment effect of controlling shareholders.

In current society, the development of companies is also inseparable from innovation, and R\&D investment is the source and internal motivation of enterprise innovation. But corporate innovation activities have two sides. On the one hand, they can bring competitive advantages to companies. On the other hand, compared with other business assets such as fixed assets, companies' innovation activities require more long-term and stable capital investment. It will occupy a large amount of funds of companies; increase the constraints of corporate funds, increase corporate risks and cause stock price fluctuations.

From the above, it can be seen that the risk faced by the controlling shareholder is also increased sharply after equity pledge, especially the risk of losing control right. The risk of control right shifting will make the controlling shareholder adjust their behavior pattern and financial decision. The shareholders may prompt the enterprise to retain the funds in the company, which in turn affects corporate innovation.

At present, the research on the impact of controlling shareholder pledge on corporate governance such as equity checks and balances and shareholding ratio is relatively mature, but the impact of controlling shareholder pledge behavior on corporate innovation activities is relatively rare in China. Therefore, this paper studies the impact of controlling shareholder pledge behavior on corporate R\&D investment.

\section{Research Significance}

\subsection{Theoretical Significance}

On the theoretical level, this paper broadens the economic consequences of the controlling shareholder's equity pledge financing. In the past, the research on the economic consequences of controlling shareholders' equity pledge mainly focused on the impact on company value, earnings management and auditor decision-making, and less associated with corporate innovation activities. This paper expands the research perspective of the controlling shareholder's pledge behavior by enriching the impact of the controlling shareholder's equity pledge on the enterprise's innovation investment, and enriches the relevant research results, which has certain theoretical significance.

\subsection{Practical Significance}

As China attaches more and more importance to innovation activities, the innovation activities of companies in research and development investment are also increasing. It is of great practical significance to analyze the influencing factors of enterprise innovation activities, because it can improve the company's innovation consciousness and strengthen its independent innovation ability 
through the research on the influencing factors of R\&D investment. The research in this paper has important reference value for the supervision department to strengthen investor protection, and provides theoretical support for companies to carry out innovative $\mathrm{R} \& \mathrm{D}$ activities more reasonably.

\section{Literature Review}

\subsection{Equity Pledge}

Equity pledge means that the controlling shareholder use their equity as the subject matter of pledge for financing, but the major shareholder still enjoys the right to operate and decide on the company after pledge, and their equity position in the company will not be affected. Wu Bingen (2001) [1] believes that the motive of equity pledge is that the company is in financial distress and needs to use the equity pledge to alleviate the financing dilemma and meet the funding needs. Gao Lanfen (2002) [2] takes the Taiwan market as the research object and believes that the motive of equity pledge is to use pledge funds to buy back shares and conduct speculation.

For this problem, the research of domestic and foreign scholars basically focuses on the economic consequences caused by shareholder equity pledge, including shareholder equity pledge on corporate earnings management, market value management, enterprise innovation and corporate value or performance. At present, there is still no unified conclusion on the economic consequences of the large shareholders' equity pledge. Therefore, this paper divides the literature on shareholder equity pledge into two parts for review and combing.

\section{1) Equity pledge plays a role in promoting the development of companies}

The main argument of this type of literature is: after controlling shareholder's equity pledge, in order to avoid the control right shifting, there is a motive for controlling shareholders to improve the performance of the listed company. Or the pledge behavior plays a role of governance and supervision, which makes the company's performance improve significantly after the equity pledge.

Wang Bin, Cai Anhui and Feng Yang (2013) [3] conduct an empirical research and believe that major shareholders of private companies are more likely to use equity pledge financing. Compared with major shareholders of state-owned companies, there is a significantly negative correlation between shareholding ratio and pledge behavior in private companies. The pledge of shareholder equity does not necessarily lead to the deviation of the two rights. Instead, it will prompt the controlling shareholder to make more efforts to improve the business performance, thus reducing the risk of transfer of control rights. In addition, Wang Bin and Song Chunxia (2015) [4] find that the pledge party as an external governance role helps to curb the accounting earnings control level and has a beneficial effect on the company's value.

Tan Yan and Wu Jing (2013) [5] use the data of A-share listed company from 2001 to 2010 to find out that pledge behavior can tie the bank's economic interests with the value of listed companies, and play a role in reducing debt agency 
costs. What' more, equity pledge of major shareholders can supervise the quality of company equity. And the higher the level of financial development, the supervisory effect of controlling shareholder equity pledge will be more obvious.

Li Wei and Zheng Guojian (2015) [6] believe that in the context of full circulation, market value management has a stable positive impact on the company's share price and will be beneficial to the controlling shareholder's equity pledge. After the equity pledge, the controlling shareholder will take the initiative to reduce the short-selling of the company and the interests of the minority shareholders in order to prevent the market value from being additionally secured by the creditors. The higher the shareholding ratio of the controlling shareholder, the governing effect will be stronger.

Lv Xiaoliang (2017) [7] obtains the following conclusions through an empirical research, equity pledge behavior increases the probability of the company being audited after violation of regulations, thereby reducing the company's tendency to violate regulations, and this phenomenon is more significant in nonstate-owned companies.

Xie Deren, Zheng Dengjin and Cui Yuyu (2016) [8] found that the risk of stock price collapse of listed companies decreased after the equity pledge, but the channel for listed companies to reduce the risk of stock price collapse is to control information disclosure rather than improve the company's performance.

\section{2) Equity pledge has a negative impact on companies}

Regarding the negative effect of shareholder equity pledge on companies, most of the literatures believe that after the equity pledge of controlling shareholders, there will be short-sightedness and encroachment behaviors. The degree of separation between control rights and cash flow rights will increase, and agency problems will intensify. And the encroachment of corporate funds, which has a negative impact on stock prices, company value, investment behavior and auditor decision-making, and enhances the incentives for listed companies' earnings management.

La Porta et al. [9] proposed in 1999 that in a country with a large concentration of shares, the research on the company should focus on the incentives and opportunities for controlling shareholders to encroach on the interests of small and medium shareholders.

Claessens (2002) [10] conducted a study on listed companies in East Asian countries and regions, and found that the relationship between company performance and equity pledge is negatively correlated, especially in areas where the company is controlled by family or the level of legal protection is low.

The research by Ronald and Michael (2015) [11] also draws the same view, but it believes that the negative correlation between equity pledge and the value of listed companies is caused by the company's risk arising from equity pledge, which exacerbates the conflicts between major shareholders and other shareholders, and then affects corporate value.

The domestic literatures about the effect of major shareholder equity pledge on the performance and value of the company mainly as follow: 
Hao Xiangchao, Liang Qi (2009) [12] point out that equity pledge behaviors weaken the incentive effect and strengthen the encroachment effect on the company value. On the one hand, after the equity pledge, the actual cash flow right of controlling shareholder declines, which reduces the consistency of the interests of the controlling shareholder and the listed company. On the other hand, after the equity pledge, the control right of shareholders still maintain. In case of a decrease of actual cash flow right, the controlling shareholder will use the control right to occupy the interests of the minority shareholders, strengthen the encroachment effect and reduce the company value.

Li Yongwei and Li Ruoshan (2007) [13] conducted a case study and explored that after the equity pledge, the controlling shareholder realizes the separation of the actual control right from the nominal cash flow right, and their interests were no longer consistent with the minority shareholders.

Liao Kaimin, Chen Yanhua (2014) [14] believe that after the pledge of equity, the separation of the two rights increases, which reduces the willingness of shareholders to issue cash dividends. And this relationship is more significant among non-state-owned listed companies. This is because the external constraints on the dividend distribution of private enterprises are relatively weak. In addition, Zhang Taoyong and Chen Yanhua (2014) [15] starting from the investment direction of pledged capital, the research result shows that the controlling shareholders are more inclined to invest the pledged funds to themselves or third parties, and the company's performance is significantly lower than that of the pledged listed companies. Zheng Guojian et al. (2014) [16] conduct a research from the angle of capital occupation and point out that the equity pledge of major shareholders is positively related to capital occupation. Chen Anlin (2013) [17] also proposed that equity pledge does not necessarily lead to an increase in the separation of the two powers. Only when the equity pledge rate is high, the equity pledge will affect the company's financial behavior.

The domestic literature about the effect of equity pledge of major shareholder on earnings management, auditor decision-making and innovation investment are included as follow:

Zhang Longping, Pan Lin, Ouyang Caiyue and Xiong Jiacai (2016) [18], from the perspective of external supervision, believe that companies with equity pledge will face major shareholders' short-selling problems and control transfer risks, but auditors can identify these risks and demand more audit fee. Li Changqing et al. (2018) [19] found that the controlling shareholder's equity pledge would inhibit corporate R\&D investment and would be more significant in companies with lower shareholding ratios and dual jobs. In addition, Li Changqing et al. find that controlling shareholders equity pledge will also affect the cash holding level of listed companies (2018) [20], sensitivity between executive compensation and listed company performance (2018) [21] and information disclosure of listed company (2017) [22]. Xie Deren and other scholars also studied the relationship between controlling shareholders' equity pledge and development expenditure accounting policy implicit selection (2017) [23], or divi- 
dend policy (2018) [24].

\subsection{Enterprise Innovation Investment}

Many scholars at home and abroad have studied the factors that influence the innovation investment of companies based on the technology innovation theory of Xiongbit. This paper divides the influencing factors of innovation investment into three aspects, including enterprise micro, industry characteristics and macro policy.

\section{1) Macro level}

As far as government policy is concerned, Berube and Mohne (2009) [25] believe that the government tax credit policy can enhance the incentives for companies to invest in $\mathrm{R} \& \mathrm{D}$, and if the company also enjoys government subsidy policies, it will have a greater incentive for R\&D innovation. Chen (2011) [26] point out that political capital can improve the company's ability to resist risks and ease the pressure on corporate R\&D funds. On the contrary, a group of scholars such as Griffith R (2004) [27] believe that government subsidies and tax incentives will produce a "crowding out effect", which will not have a substantial impact on the $\mathrm{R} \& \mathrm{D}$ and innovation activities of companies, but will result in unreasonable resource allocation in the whole capital market.

Domestic research mainly is included as follow: Yang Yang (2015) [28] and Zhang Jie (2015) [29] believe that government subsidies and preferential behaviors will promote companies to increase investment in research and development funds. Dai Chen and Liu Yi (2015) [30], Shao Cheng and Wang Shengguang (2010) [31] figure out that promoted tax incentives are more effective than government subsidies.

In terms of the institutional environment, Bellettini (2013) [32] believes that if corporate executives have long-term interests and relationships with government officials, it is not conducive to R\&D innovation, because the resulting resource advantages and competitive advantages will inhibit corporate innovation demand. Acharya and Subramanian (2009) [33], Han et al. (2016) [34] study the impact on corporate innovation from perspective of legal system development. Similarly, Ginarte (1997) [35] concluded an empirical research and find that in developed countries, there is a positive correlation between intellectual property protection and technological progress and innovation, while there is no significant relationship or even negative effect between the two in developing countries. What's more, Wang Xianbin (2010) [36] finds that when a new round of official turnover and handover occurs, enterprises predict that this will lead to major changes in policies and therefore reduce the scale of innovation investment.

\section{2) Industry level}

Holly (1998) [37] believes that in the fierce market competition, in order to maintain its own competitiveness, companies must increase their investment in innovation and develop more new products. Guo and Jiang (2013) [38] and Ag- 
hion (2013) [39] find that institutional investors can provide more financial support for companies and more supervision for business operations of those companies, so companies with institutional investors will invest more in R\&D investment. Kelly and Ljungqvist (2012) [40] believe that analysts' attention can alleviate the adverse selection problem caused by information asymmetry, so it can reduce the cost of capital and increase the investment of innovation. On the contrary, He and Tian (2013) [41] believe that after analysts pay more attention to the enterprise, the enterprise management expects to achieve better performance in a short period of time, so it will reduce the long-term R\&D investment activities with long investment cycle and high risk.

\section{3) Enterprise level}

Malmendier (2005) [42], Du (2011) [43], Xu (2012) [44] and Bereskin (2014) [45] found that the innovation input of enterprises is related to CEO characteristics, including CEO's new appointment, CEO's tenure, CEO's age, education level and incentive level.

Zhang Yetao et al. (2012) [46] obtain the conclusion that with the increase of senior managers' shareholding ratio, the R\&D investment will increase accordingly. Xie Zhen (2014) [47] believes that when managers face the risk of being replaced, they will reduce the investment in innovation in order to improve short-term performance. Specifically, analysts can only make short-term forecast analysis generally, which will increase the pressure of managers, so managers will choose to invest less company innovation to avoid risks. Tang Yuejun and Zuo Jingjing (2014) [48] from the perspective of corporate governance, find that the deviation of the two rights of the ultimate controlling shareholder is detrimental to the company's innovation to a certain extent, but for listed company controlled by a family or natural person, the deviation can help to increase R \& $\mathrm{D}$ investment.

\subsection{Literature Review}

Domestic and foreign scholars have increasingly studied the factors influencing the innovation investment of companies. From the literature review, there are many factors that affect the innovation investment of companies. We can see that macro and micro-environment as well as industry factors, which include fiscal policy, legal system development level, economic development level, the analysts' concerns, the internal corporate executive characteristics, the shareholding structure and the financing constraints, both have effect on company innovation investment. However, little researches have been done on the relationship between shareholder pledge behavior and innovation input.

As for the controlling shareholder's equity pledge, it can be seen that the scope of its research is generally focused on the characteristics of controlling shareholders and company value, earnings management, market value management, stock price collapse and investment behavior. However, there is no uniform conclusion in the academic circles on whether the pledge of equity plays a posi- 
tive role or a negative role in encroachment.

From the perspective of controlling shareholders' equity pledge, this paper studies the influence of controlling shareholders' equity pledge on enterprise innovation activities, further enriches the research in related fields, and plays a theoretical reference role in increasing innovation investment and government departments to improve the equity pledge system regulations.

\section{Hypotheses Proposed}

\subsection{Equity Pledge and Innovation R\&D Investment Level}

After the equity pledge of controlling shareholder, if the stock price declines, which make the value of the pledge decrease, the pledge party has the right to request the pledgee to add additional guarantees or offer other additional insurance measures. When the controlling shareholder cannot add the guarantee, creditors can sell out the stocks that are pledged by the controlling shareholder. Under these circumstances, the shareholders may lose their control rights of listed companies. When all the pledged stocks are disposed of, the amount of pledge financing is still insufficient. The controlling shareholder not only has to bear the risk of control rights shifting, but also faces the remaining debt repayment risk.

An effective way to reduce the risk of control rights transfer caused by the controlling shareholder's equity pledge is that listed companies can provide sufficient cash flow income or seek to reduce cash expenditure, which can increase the cash holding level, when stock price hit the open line

However, research and development activities need a huge amount of stable capital of listed companies, and have the characteristics of long cycle and high uncertainty. Once the R\&D activities fail, it will sharply increase listed company's risks and have huge negative impact on stock price. Based on this, the controlling shareholder will increase their risk aversion when the stock price hit the open line, and have more motivation to reduce the R\&D investment and increase the cash flow holding level, to deal with the control transfer risk.

In addition, due to the weak external governance environment in China, controlling shareholders are more likely to encroach on the interests of minority shareholders. And the controlling shareholder equity pledge is negative information for the external shareholders of listed companies, and thus might strengthen the financing constraints of listed companies. Undoubtedly, this will be greatly limited for those financially dependent $\mathrm{R} \& \mathrm{D}$ activities.

In short, on the one hand, controlling shareholders will actively reduce investment in innovation in order to reduce the risk of control transfer and debt repayment; on the other hand, passive signals conveyed by pledge behavior will increase the difficulty of corporate financing, thus passively selecting a lower level of innovation input.

Based on this, the following assumptions are made.

$\mathrm{H1}$ : When approaching the liquidation line, there is a negative correlation between the equity pledge of controlling shareholder and the innovation invest- 
ment of company.

\subsection{Nature of Property Rights, Equity Pledge and R\&D Investment}

Affected by the historical evolution and the special institutional background of China, state-owned companies are subject to more government intervention. For companies with different property rights, the controlling shareholder's equity pledge may have different effects on corporate innovation investment.

First of all, the problem of absence of owners has made the issue of principal-agent of state-owned companies more complicated and serious. At the same time, state-owned companies need to consider economic and social benefits at the same time, so they will choose more stable and low-risk investment projects, and less investment in innovative projects with high uncertainties and high risks. Secondly, when state-owned companies face the decline of long-term development potential and future performance, the government will support through taxation policies and subsidy policies, so the incentives for managers to invest in $\mathrm{R} \& \mathrm{D}$ will be weakened.

On the contrary, the controlling shareholders of non-state-owned companies are generally one of the founders of the companies, the owners and operators may be more consistent in their goals and pay more attention to the long-term development of the companies. And non-state-owned companies are faced with a more severe market competition environment. Based on this, although the controlling shareholder's reduction of R\&D investment can reduce the risk of equity pledge, but it also has to bear the cost of the company's long-term development potential due to insufficient innovation ability, so small companies will be more inclined to adopt technology innovation to increase their own competition.

In summary, the demand for $\mathrm{R} \& \mathrm{D}$ investment of state-owned companies is relatively flexible, while the $R \& D$ investment of non-state-owned companies is a rigid demand. Therefore, when there is a controlling shareholder to carry out equity pledge, the negative impact of state-owned companies is greater, and the impact of non-state-owned companies is less.

Based on this, the following assumptions are made.

H2: Compared with non-state-owned companies, the negative correlation between the controlling shareholder equity pledge of state-owned companies and R\&D investment is more significant.

\section{Research Design}

\subsection{Sample Selection and Variable Definitions}

The controlling shareholder pledge data of this paper comes from the Wind database, and a small amount of missing data is manually collected and supplemented from the annual report. Since the disclosure of equity pledge data is very few before 2010, this paper selects all A-share listed companies from 2010 to 2017 as a research object. Other financial data and patent data are from the CSMAR database. 
In the sample selection process, the sample is selected according to the following conditions: 1) excluding the listed companies belonging to the financial industry; 2) excluding the IPO sample of the current year and the companies that have been delisted; 3) excluding the samples with missing data; 4) excluding listed companies that have implemented abnormal status such as ST. In order to eliminate the influence of outliers on the estimation results, this paper performs a tail-ending treatment on the upper and lower $1 \%$ of all continuous variables. Finally, a total 10056 observations were obtained.

The specific definition of the variable is as Table 1.

\subsection{Model Setting}

In order to test hypothesis 1, the Equation (1) is conducted:

$$
\mathrm{RD}_{i, t}=\alpha+\beta_{i} * \operatorname{Pr}_{i, t}+\sum \beta_{m} \text { control }_{i, t}+\varepsilon_{i} .
$$

\section{Empirical Research Results and Analysis}

\subsection{Descriptive Statistics of Main Variables}

Table 2 shows the results of descriptive statistics of the main variables. From the table, we can observe that the maximum and minimum value of R\&D investment is 0.99 and 0.03 respectively, which indicates that the listed companies have different emphasis on $\mathrm{R} \& \mathrm{D}$ investment. What's more, the proportion of equity pledge of controlling shareholders is 0.43 , and the average ratio of shares pledged to the total shares is 0.15 , which shows that equity pledge has become a normal practice for controlling shareholders to pledge their shares in China's capital market.

\subsection{Results of Regression Analysis}

Table 3 shows the results of the regression analysis. The first column shows the

Table 1. Variable definitions.

\begin{tabular}{|c|c|}
\hline Variable symbol & Variable interpretation \\
\hline $\mathrm{RD}$ & $\mathrm{LN}(\mathrm{R} \& \mathrm{D}$ investment/total assets +1 ) \\
\hline Pledge_ratio (Pr) & $\begin{array}{l}\text { Equity pledge ratio, the ratio of the number of shares pledged by controlling } \\
\text { shareholders to the number of shares held }\end{array}$ \\
\hline Pledge_dum (Pd) & $\begin{array}{l}\text { Dummy variable, the stock pledge of the controlling shareholder in the current } \\
\text { year is } 1 \text {, otherwise } 0\end{array}$ \\
\hline Size & Company size, logarithm of total assets \\
\hline Lev & Financial leverage, total liabilities divided by total assets \\
\hline Cfo & Cash flow capacity, free cash flow to total assets \\
\hline Growth & Revenue growth rate \\
\hline Independ & $\begin{array}{l}\text { Independence, the ratio of the number of independent directors to the board of } \\
\text { directors }\end{array}$ \\
\hline SOE & Dummy variable, state-owned enterprise is 1 , otherwise is 0 \\
\hline
\end{tabular}


Table 2. Descriptive statistics.

\begin{tabular}{ccccccc}
\hline Variable & Sample size & mean & sd & median & min & $\max$ \\
\hline $\mathrm{RD}$ & 10056 & 0.04 & 0.04 & 0.00 & 0.03 & 0.99 \\
$\mathrm{Pr}$ & 10056 & 0.15 & 0.28 & 0.00 & 0.00 & 1.00 \\
$\mathrm{Pd}$ & 10056 & 0.43 & 0.43 & 0.00 & 0.00 & 1.00 \\
Size & 10056 & 21.52 & 1.12 & 21.36 & 18.86 & 26.50 \\
Lev & 10056 & 0.40 & 0.20 & 0.39 & 0.05 & 1.42 \\
Cfo & 10056 & 0.04 & 0.07 & 0.04 & -0.16 & 0.23 \\
Growth & 10056 & 0.20 & 0.48 & 0.12 & -0.72 & 4.57 \\
Independ & 10056 & 0.37 & 0.05 & 0.30 & 0.33 & 0.57 \\
SOE & 10056 & 0.41 & 0.49 & 0.00 & 0.00 & 1.00 \\
\hline
\end{tabular}

Table 3. Results of regression analysis.

\begin{tabular}{|c|c|c|c|c|}
\hline \multirow{2}{*}{ Variable } & \multirow{2}{*}{ (1) $\mathrm{RD}$} & \multirow{2}{*}{ (2) $\mathrm{RD}$} & \multicolumn{2}{|c|}{$\mathrm{RD}$} \\
\hline & & & (3) State-owned & (4) Non-state owned \\
\hline $\mathrm{Pd}$ & $\begin{array}{c}-0.03^{\star * *} \\
(-1.92)\end{array}$ & & & \\
\hline $\operatorname{Pr}$ & & $\begin{array}{c}-0.003^{\star *} \\
(-2.03)\end{array}$ & $\begin{array}{c}-0.011^{\star * *} \\
(-1.72)\end{array}$ & $\begin{array}{l}-0.006 \\
(-0.57)\end{array}$ \\
\hline Size & $\begin{array}{l}0.01^{*} \\
(0.61)\end{array}$ & $\begin{array}{c}0.01^{* * *} \\
(4.94)\end{array}$ & $\begin{array}{c}-0.004^{* * *} \\
(-5.87)\end{array}$ & $\begin{array}{c}-0.053^{\star * *} \\
(-4.9)\end{array}$ \\
\hline Lev & $\begin{array}{l}-0.00 \\
(-0.08)\end{array}$ & $\begin{array}{l}-0.00 \\
(-1.13)\end{array}$ & $\begin{array}{c}-0.028^{\star * *} \\
(-3.89)\end{array}$ & $\begin{array}{c}-0.063^{* * *} \\
(-10.41)\end{array}$ \\
\hline Cfo & $\begin{array}{l}0.03^{\star} \\
(0.41)\end{array}$ & $\begin{array}{l}0.01^{\star *} \\
(1.92)\end{array}$ & $\begin{array}{l}-0.04^{*} \\
(-3.49)\end{array}$ & $\begin{array}{l}-0.022 \\
(-1.83)\end{array}$ \\
\hline Growth & $\begin{array}{l}0.00^{\star} \\
(0.65)\end{array}$ & $\begin{array}{c}0.01^{* *} \\
(12.16)\end{array}$ & $\begin{array}{c}0.003^{* *} \\
(3.16)\end{array}$ & $\begin{array}{l}0.001 \\
(0.90)\end{array}$ \\
\hline Independ & $\begin{array}{l}-0.07 \\
(-0.67)\end{array}$ & $\begin{array}{l}0.02^{\star *} \\
(2.09)\end{array}$ & $\begin{array}{l}0.005 \\
(0.28)\end{array}$ & $\begin{array}{l}0.040^{* *} \\
(2.26)\end{array}$ \\
\hline Ind/year & Yes & Yes & Yes & Yes \\
\hline Observation & 10056 & 10056 & 10056 & 10056 \\
\hline R-sq & 0.01 & 0.05 & 0.064 & 0.1136 \\
\hline
\end{tabular}

results of the relationship between whether the controlling shareholder has equity pledge behaviors and the R\&D investment of the company. We can see that the correlation coefficient is -0.03 , statistically significant at the $1 \%$ level. The size, cash flow and growth of the company both have positive impact on company innovation investment. And the second column shows the results of the relationship between the equity pledge ratio of controlling shareholders and the R\&D investment level of companies. After replacing the controlling shareholder's equity pledge as a dummy variable with the equity pledge scale variable $\mathrm{Pr}$, the correlation is still significantly negative at the $5 \%$ level. Above analysis sup- 
ports the hypothesis 1 with strong explanatory power. In terms of control variables, there is a significant negative correlation between leverage and company R\&D investment, while cash flow ratio, growth and company size have a significant positive correlation with company $R \& D$ investment, basically consistent with the research conclusions of other scholars.

The third and the fourth column in Table 3 show the regression results of the nature of corporate property rights, controlling shareholder pledge and corporate innovation. When the company is state-owned, the coefficient of $\mathrm{Pr}$ and $\mathrm{R} \& \mathrm{D}$ is -0.011 , which is significant at the level of $1 \%$. When the company is non-state-owned, the coefficient is -0.006 , but the negative relationship is no longer statistically significant. This is consistent with the expectation of hypothesis $\mathrm{H} 2$.

\section{Conclusions}

After sorting out the related literature on the influencing factors of R\&D investment and the economic consequences of controlling shareholders' equity pledge behaviour, this paper selects the data of China's Shanghai and Shenzhen A-share listed companies in 2010-2017 as a research sample, and conducts empirical analysis on the relationship between equity pledge of controlling shareholder and the company R\&D investment. The study found that equity pledge and equity pledge ratio are significantly negatively correlated with company R\&D investment. And compared with non-state-owned company, the negative correlation between equity pledge of controlling shareholder and R\&D investment is more significant in state-owned listed company.

But there are some limitations in this paper. The controlling shareholders may pledge or decompress their equity for many times in a fiscal year, so the pledge rate is in a fluctuating state, but the controlling shareholders pledge or release the pledge behavior is too frequent, and it is difficult to make statistics. So this paper explains that the selection of the variables of the controlling shareholders' cumulative pledge rate on the balance sheet date of that year may cause some deviations in the research conclusion.

In view of the fact that equity pledge may reduce company innovation activities of enterprises and affect the operating performance of listed companies in the future, government departments should improve laws and regulations on equity pledge, strengthen supervision over the equity pledge behavior of controlling shareholders.

\section{Conflicts of Interest}

The author declares no conflicts of interest regarding the publication of this paper.

\section{References}

[1] Wu, B.G. (2001) Research on the Relationship between Equity Pledge and Stock 
Price of Internal Related Parties in Taiwan's Electronic Listed Companies. Institute of Financial Management, National Kaohsiung University of Science and Technology, Kaohsiung, Taiwan, China.

[2] Gao, L.F. (2002) The Impact of Equity Pledge of Directors and Supervisors on Accounting Information and Corporate Performance. Ph.D. Dissertation, National University of Success, Taiwan, China.

[3] Wang, B., Cao, A.H. and Feng, Y. (2013) The Equity Pledge of Large Shareholders, the Risk of Control Transfer and the Performance of the Company. Systems Engineering-Theory \& Practice, 33, 1762-1773.

[4] Wang, B. and Song, C.X. (2015) The Equity Pledge of Large Shareholders, the Nature of Equity and the Management of Earnings. East China Economic Management, 29, 118-128.

[5] Tan, Y. and Wu, J. (2013) Does Equity Pledge Have Governance Utility?-Evidence from Chinese Listed Companies. Accounting Research, No. 2, 45-53+95.

[6] Li, W. and Zheng, G.J. (2015) The Controlling Shareholder's Equity Pledge Financing and Interest Encroachment under the Motive of Market Value Management. Accounting Research, No. 5, 42-49.

[7] Lv, X.L. (2017) Equity Pledge of Controlling Shareholders and Corporate Violation. The Journal of Finance and Economics of Shanxi University, No. 11, 84-96.

[8] Xie, D.R., Zheng, D.J. and Cui, Y.Y. (2016) Is the Controlling Shareholder's Equity Pledge a Potential "Land Mine"?-Based on the Perspective of Stock Price Collapse Risk. Management World, No. 5, 128-140.

[9] Porta, R.L. and Shleifer, L.D.S. (1999) Corporate Ownership around the World. The Journal of Finance, 54, 471-517. https://doi.org/10.1111/0022-1082.00115

[10] Claessens, S., Djankov, S., Fan, J.P.H. and Lang, L.H.P. (2002) Disentangling the Incentive and Entrenchment Effects of Large Shareholdings. The Journal of Finance, 57, 2741-2771. https://doi.org/10.1111/1540-6261.00511

[11] Ronald, A. and Michael, P. (2015) Insider Share-Pledging and Firm Risk. Working Paper.

[12] Hao, X.C. and Liang, Q. (2009) Is the Ultimate Controller's Equity Pledge Damaging the Company's Value? Accounting Research, No. 7, 57-63.

[13] Li, Y.W. and Li, R.S. (2007) “Tunnel Excavation" under the Pledge of Equity of Listed Companies-Case Analysis of Star Power Black Hole. Finance and Accounting, No. 2, 39-42.

[14] Liao, K.M., Chen, Y.H., Ding, H.J., Zhang, R.X., Dong, C.P. and Li, R. (2014) Research on the Influence of Controlling Shareholder's Equity Pledge on Cash Dividend Distribution Tendency. China Management Information, 17, 116-118.

[15] Zhang, T.Y. and Chen, Y.H. (2014) Equity Pledge, Capital Investment and Corporate Performance-Based on Empirical Data of Equity Pledge of Controlling Shareholders of Listed Companies in China. The Journal of Nanjing Audit University, 11, 63-70.

[16] Zheng, G.J., Lin, D.J. and Lin, B. (2014) Equity Pledge, Occupation and Enterprise Value of Large Shareholders. The Journal of Management Sciences, 17, 72-87.

[17] Chen, A.L., Gao, L.F., Chen, Y.K., et al. (2013) Research on the Equity Pledge of Dong Supervisor and Corporate Governance. Management Review of Zhongshan, No. 2, 299-335.

[18] Zhang, L.P., Pan, L., Ouyang, C.Y., et al. (2016) Does the Controlling Shareholder's Equity Pledge Affect the Auditor's Pricing Strategy?-Empirical Evidence from 
Chinese Listed Companies. Audit and Economic Research, 31, 35-45.

[19] Li, C.Q., Li, Y.K. and Li, M.L. (2018) Controlling Shareholder Pledge and Enterprise Innovation Investment. Financial Research, No. 7, 143-157.

[20] Li, C.Q., Xing, W. and Li, M.L. (2018) Equity Pledge and Cash Holding Level of Controlling Shareholders: "Hollowing out" or "Avoiding the Risk of Control Transfer". Finance and Trade Economy, 39, 82-98.

[21] Li, C.Q. and Xing, W. (2018) Does the Pledge of Controlling Shareholder's Equity Affect Executive Compensation Performance Sensitivity? Economic Management, 40, 157-174.

[22] Li, C.Q. and Xing, W. (2017) Equity Pledge of Controlling Shareholders and Information Disclosure of Listed Companies. Statistical Research, 34, 75-86.

[23] Xie, D.R., Liao, W. and Zheng, D.J. (2017) The Implicit Choice of Accounting Policies for Controlling Shareholders' Equity Pledge and Development Expenditure. Accounting Research, No. 3, 30-38.

[24] Liao, K., Cui, C.Y. and Xie, D.R. (2018) Equity Pledge of Controlling Shareholders and Dividend Policy Choice of Listed Companies. Financial Research, No. 4, 172-189.

[25] Bérubé, C. and Mohnen, P. (2009) Are Firms that Receive R\&D Subsidies More Innovative? Canadian Journal of Economics/ Revue Canadienne Déconomique, 42, 206-225. https://doi.org/10.1111/j.1540-5982.2008.01505.x

[26] Chen, S., Sun, Z., Tang, S., et al. (2011) Government Intervention and Investment Efficiency: Evidence from China. The Journal of Corporate Finance, 17, 259-271. https://doi.org/10.1016/j.jcorpfin.2010.08.004

[27] Griffith, R. and Reenen, R.J.V. (2004) Mapping the Two Faces of R\&D: Productivity Growth in a Panel of OECD Industries. The Review of Economics and Statistics, 86, 883-895. https://doi.org/10.1162/0034653043125194

[28] Yang, Y., Wei, J. and Luo, L.J. (2015) Who Is Using Government Subsidies to Innovate?-The Joint Adjustment Effect of Ownership and Factor Market Distortions. Management World, No. 1, 75-86.

[29] Zhang, J., Chen, Z.Y., Yang, L.X., et al. (2015) Performance Evaluation of China's Innovation Subsidy Policy: Theory and Evidence. Economic Research, No. 10, 4-17.

[30] Dai, C. and Liu, Y. (2015) Comparative Analysis of the Influence of Tax Preference and Financial Subsidy on R\&D of Enterprises. Economic Science, 30, 58-71.

[31] Shao, C. and Wang, S.G. (2010) Structural Equation Model Analysis of the Relationship between Tax Preference and R\&D Investment of Software Enterprises in China. Industrial Technology Economy, No. 1, 64-69.

[32] Bellettini, G., Ceroni, C.B. and Prarolo, G. (2013) Persistence of Politicians and Firms' Innovation. Economic Inquiry, 51, 2056-2070. https://doi.org/10.1111/ecin.12015

[33] Acharya, V.V. and Subramanian, K.V. (2009) Bankruptcy Codes and Innovation. Review of Financial Studies, 22, 4949-4988. https://doi.org/10.1093/rfs/hhp019

[34] Han, M.N. and Wang, F.S. (2016) Legal Environment, Financial Information and Innovation Performance. Nankai Business Review, No. 19, 40.

[35] Ginarte, J.C. and Park, W.G. (1997) Determinants of Patent Rights: A Cross-National Study. Research Policy, 26, 283-301. https://doi.org/10.1016/S0048-7333(97)00022-X

[36] Wang, X.B., Xu, X.X. and Zhou, J.X. (2010) Promotion Incentive and Investment Cycle: Evidence from Chinese Provincial Officials. China Industrial Economy, No. 
$12,16-26$.

[37] Raider, H.J. (1998) Market Structure and Innovation. Social Science Research, 27, 1-21. https://doi.org/10.1006/ssre.1997.0608

[38] Guo, D. and Jiang, K. (2013) Venture Capital Investment and the Performance of Entrepreneurial Firms: Evidence from China. The Journal of Corporate Finance, 22, 375-395. https://doi.org/10.1016/j.jcorpfin.2013.07.001

[39] Aghion, P., Reenen, J.V. and Zingales, L. (2013) Innovation and Institutional Ownership. CEPR Discussion Papers, 103, 277-304.

https://doi.org/10.1257/aer.103.1.277

[40] Kelly, B. and Ljungqvist, A. (2012) Testing Asymmetric-Information Asset Pricing Models. The Review of Financial Studies, 25, 1366-1413. https://doi.org/10.1093/rfs/hhr134

[41] He, J. and Tian, X. (2013) The Dark Side of Analyst Coverage. The Journal of Financial Economics, 109, 856-878. https://doi.org/10.1016/j.jfineco.2013.04.001

[42] Malmenier, U. and Tate, G. (2005) CEO Overconfidence and Corporate Investment. The Journal of Finance, 60, 2661-2700.

https://doi.org/10.1111/j.1540-6261.2005.00813.x

[43] Du, C. and Lin, T.T. (2011) CEO Turnover, Equity-Based Compensation and Firm's Investment Decisions. The Journal of Business \& Economic Research, 9, 19-40. https://doi.org/10.19030/jber.v9i8.5292

[44] Xu, J. (2012) R\&D Investment around CEO Turnover. Working Paper, Rutgers University, New Brunswick.

[45] Bereskin, F.L. and Hsu, P.H. (2014) Bringing in Changes: The Effect of New CEOs on Innovation. Working Paper, University of Delaware, Delaware.

[46] Zhang, Y.T., Wang, C.J. and Liu, J.H. (2012) Research on the Impact of Executive Stock Ownership on Enterprise Innovation Investment-Empirical Evidence from GEM Listed Companies. Finance and Accounting Communication, No. 6, 134-138+ 163.

[47] Xie, Z. and Ai, C.R. (2014) Analyst Guan Wang and R\&D Investment of the Company: An Analysis of China's Growth Enterprise Market Company. Financial Research, 40, 108-119.

[48] Tang, Y.J. and Zuo, J.J. (2014) Ownership Nature, Large Shareholder Governance and Corporate Innovation. Financial Research, No. 408, 181-196. 